\title{
Human resource system as innovation for organisations
}

\author{
Túlio Gomes Mauro and Jairo Eduardo Borges-Andrade \\ PSTO, Universidade de Brasilia, Brasilia, Brazil
}

\begin{abstract}
Purpose - This paper aims to identify relevant aspects to achieve advantage of the innovative potential of a human resource information system (HRIS). The present study compared the system implementation professionals' perception of the results expected from the system, its characteristics and how it should be implemented.

Design/methodology/approach - Semi-structured interviews were conducted with eight information technology specialists and ten human resource (HR) professionals from four organisations at different stages of HRIS implementation, in which two had it fully implemented and two were undergoing the implementation process. The resulting data were submitted to four sets of content analyses and then compared.

Findings - Findings suggest specificities in the perception of these professionals. Critical aspects regarding the effective adoption of HRIS were addressed, such as characteristics of the systems, implementation process and human resource management model.

Originality/value - The implementation of an HRIS alone does not ensure the achievement of the obtained advantages. The results of the present study provide guidelines for implementation of HRIS as innovation for a strategic management of people. These guidelines come from different knowledge areas and from different stages of implementation. These findings corroborate models of innovation diffusion and technology acceptance.
\end{abstract}

Keywords Innovation, Human resource information system, Strategic human resource, System implementation, Human resources

Paper type Research paper

\section{Introduction}

Human capital resources are a critical factor for organisations seeking to achieve competitive advantage (Crook, Todd, Combs, Woehr, \& Ketchen, 2011; Kraiger, Passmore, Santos, \& Malvezzi, 2015). The implementation of human resource information systems (HRIS) is notoriously highlighted among the recent initiatives adopted to innovate human resource (HR) management. Information technology seems to be a key facilitator for establishing innovative policies and practices of intellectual capital development (Noe, Clarke, \& Klein, 2014).

Organisations seek to adopt innovations for improving their performance and respond efficiently to their environmental demands (Damanpour \& Schneider, 2006). However, the implementation of innovations alone does not necessarily result in gains for the organisation. This happens because innovation is not an isolated act but one dependent on a

(C) Túlio Gomes Mauro and Jairo Eduardo Borges-Andrade. Published in Innovation and Management Review. Published by Emerald Publishing Limited. This article is published under the Creative Commons Attribution (CC BY 4.0) licence. Anyone may reproduce, distribute, translate and create derivative works of this article (for both commercial and non-commercial purposes), subject to full attribution to the original publication and authors. The full terms of this licence may be seen at http://creativecommons.org/licences/by/4.0/legalcode
Received 28 March 2019 Revised 5 October 2019 Accepted 9 October 2019
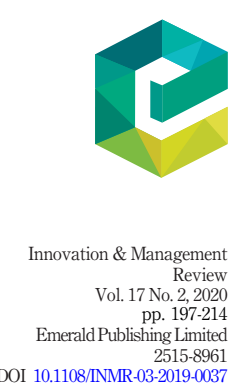
INMR

17,2

network of combined actions aimed to improve the organisation's competitiveness (Alves, Galina, \& Dobelin, 2018). The implementation of HRIS alone does not enable the organisation to achieve advantage from resulting benefits. The system by itself cannot lead to a competitive advantage. This advantage will be achieved through the best fit between system, HR management model, strategic capacities and business processes (Kavanagh \& Johnson, 2015).

How individuals perceive the characteristics of an innovation is essential for explaining the different rates of adoption (Rogers, 2003). Therefore, the way a system is implemented in an organisation and how individuals perceive this new element are crucial for its efficacy (Venkatesh \& Bala, 2008). Low acceptance and use of systems have been the major barriers to the successful implementation projects, thus resulting in great financial losses (Rogers, 2003).

Many systems are acquired, developed and implemented without considering key aspects for their acceptance and use. Perception and interpretation of these systems need to be taken into consideration so that the organisations can benefit from the innovative potential of a HRIS. In view of this problem, the following may be questioned: How do individuals involved in the implementation of a HRIS perceive its potentialities, characteristics and implementation process? Do professionals from different areas and at different stages of the implementation process share a homogeneous view of what they are acquiring and for what? Do these professionals emphasise the same aspects of the implementation process?

The objective of the present study was to compare the perceptions of individuals involved in the implementation of HRIS on:

- the results it should produce;

- the characteristics it should have; and

- how it should be implemented.

Information technology and HR professionals, who were at different stages of the system implementation process, were interviewed. The analyses of these interviews sought to identify the importance attributed to different aspects regarding the system and how the answers converged and diverged among categories.

The HRIS features and the way by which individuals responsible for its implementation perceive and interpret these aspects are important for its effectiveness. In general, these individuals are major decision-makers and they may substantially influence the choice of a system and the way by which it should be implemented. The answer to the questions proposed in this study is important, because their possible patterns may suggest risks to the success of this type of initiative. Investigation on the perception reported by those professionals who seek this kind of system leads to the identification of relevant aspects. Thus, the organisation may benefit from the system's innovative potential. This innovative potential corresponds to the improvement of the strategic management of people (Kavanagh \& Johnson, 2015) and to the strengthen of the HR department role as a business partner of the organisation (Kossek, Young, Gash, \& Nichol, 1994).

In general, studies on HRIS separately address its characteristics, potentialities and implementation process. The present study assesses the whole perceptions of these issues. It follows the evolution trend in this research field (Johnson, Lukaszewski, \& Stone, 2016). Its originality evolves from the comparison of four sets of content analyses and from the integration of the views from different professionals in diverse contexts. Moreover, this study addresses the professionals' perception of how they may achieve an adjustment 
between system and management models. This is crucial for organisations to attain competitive advantage from HRIS (Bedell, 2003; Bedell \& Caniff, 2015; Cadle \& Yeates, 2008; Kavanagh \& Johnson, 2015). The perspective adopted by the study may raise reflexions on how the organisation could actually implement and use HRIS. The findings raised may guide the implementing professionals on the acquisition, development and implementation of information systems.

\section{Human resource information systems}

HRIS is defined as a composition of database, computer application, hardware and software needed to collect, store, manage, deliver, present and manipulate data on HR (Broderick \& Boudreau, 1992). These systems are small specific applications encompassing a unique management process or are an integrated business management architecture implemented at large scale. They may also involve different types of HR processes (i.e. recruitment, selection, assessment and development) and provide support at different organisational levels (i.e. operational, managerial, strategic and executive). A strategic HRIS provides highlevel aggregate data, assists long-term planning managers and supports strategic decisions (Bondarouk \& Ruel, 2010).

In the 1960s, the first HR systems were run for storage of data on employees and descriptions of work positions. They included payroll processing, which was one of the first functions provided by a HRIS (Fletcher, 2005; Tannenbaum, 1990). From the 1970s on, USA companies began to be systematically demanded by society for following new labour laws. Such laws included the prohibition of discriminatory practices and the promotion of occupational health and safety, according to these authors. These demands created the need to increase efficacy and to control HR processes. As a response to these demands, companies begun to implement HRIS. During that time, however, only large organisations were able to acquire and use this kind of system.

From the 1990s on, the investments in hiring and developing personnel needed to be justified. At the beginning of the twenty-first century, human capital was highlighted as a source of competitive advantages for organisations. Therefore, HRIS began to play a strategic role within the organisation as it enabled actions for human capital orientation to achieve objectives and strategic goals (Fletcher, 2005; Kavanagh \& Johnson, 2015).

Even after four decades of research on the use of technology for supporting HR practices, this field has only begun to deepen into issues, which may actually benefit managers and organisations (Johnson et al., 2016). Studies on HRIS-related issues published between 1967 and 2014 were reviewed by these authors. Their findings showed that 34 per cent of all studies were of a theoretical nature, 30 per cent were experimental, 22 per cent were data survey and 14 per cent were case studies. Most of these studies (63 per cent) addressed systems of enterprise resource planning (ERP). Recruitment and selection (52.7 per cent) and implementation process (16 per cent) were the most common objectives. As a research agenda suggested the evolution of HRIS research field should encompass studies aimed at integrating multiple knowledge areas (Johnson et al., 2016). Another research agenda emphasised that such an evolution involves the study of Internet-based applications with cloud storage (Ngai \& Wat, 2006).

Given the assumptions that HRIS enables the adoption of new HR management policies and practices and that it does not specifically consider the organisation's essential processes, HRIS is classified as administrative process innovations (Damanpour, Walker, \& Avellaneda, 2009). Innovations of this kind are defined as being new approaches or practices aimed at motivating and rewarding the organisation's employees. They also aim at conceiving structures of tasks and changing the organisation's management process. 
INMR

17,2

200

The innovative potential of HRIS relies on the improvement of the strategic management of people (Kavanagh \& Johnson, 2015). The implementation of HRIS enables to strengthen the HR department's role as a business partner, according to Kossek et al. (1994). The implementation of HRIS may change the power dynamics in which HR department is involved, as well as its standard of communication with the organisation, emphasise these authors.

Despite being risky and having no guarantee of success, innovations are implemented to achieve advantages for the organisations (Damanpour \& Schneider, 2006). The possible advantages provided by a HRIS involve optimisation of HR processes, automatic production of different reports, integration of individuals and information sharing (Ngai \& Wat, 2006). "When managers harness information technology to their strategic goals, they usually plan to accomplish one or more of three independent operational objectives: to increase the continuity (functional integration, intensified automation, fast response), the control (precision, accuracy, predictability, consistency, certainty) and the comprehensibility (visibility, analysis, synthesis) of productive functions" (Zuboff, 1994, p. 82).

Small companies are less likely to use HRIS and when they do so, they assume a nonstrategic administrative function (Ball, 2001; Ngai \& Wat, 2006). Individuals who experienced the implementation and use of HRIS have a more homogeneous perception of the benefits and difficulties created by the system, whereas those who did not experience this process just seem to speculate on these aspects (Ngai \& Wat, 2006).

The debate on the possible strategic advantages provided by these systems is not finished at all. Some researchers state that HRIS may promote strategic advantages for an organisation, whereas others point to a lack of strategic change indicators as a result of the implementation of these systems. Nevertheless, there is a group of researchers suggesting that these systems may generate strategic values under certain conditions (Bondarouk \& Ruel, 2010).

Three possible conditions, which may influence the effective use of HRIS by members of organisations may be highlighted:

(1) aspects related to the implementation process (Kavanagh, 2015);

(2) users' perception of the characteristics of the system (Venkatesh \& Bala, 2008); and

(3) quality of the automated model of HR management (McHenry \& Stronen, 2008).

These three sets of possible conditions are detailed below.

\section{Human resource information system implementation process}

Aspects related to the implementation process were identified as being essential for an organisation to achieve benefits from the HRIS (Kavanagh, 2015). The implementation process of a system acquired by an organisation occurs within a project structure. This project usually has different phases with specific objectives. Several cases of unsuccessful implementation were attributed to a "loss of project control", reports this author. Therefore, project management methodologies and tools should be used.

Some questions regarding problems in HRIS implementation projects were raised by Kavanagh (2015). One of them deals with the end user's satisfaction with the system's aspects. System developers create applications they deem convenient for the user, argues this author. However, as developers do not usually know how HR management works, users may become unsatisfied with the resulting applications. The authors emphatically recommend that the HRIS implementation team should have a professional who understands the business rules for $\mathrm{HR}$. 
The above-mentioned question refers to the process of system requirement elicitation. This process corresponds to the collection of information about required functionalities. It is widely recognised as the most difficult activity in the system development process (Browne $\&$ Rogich, 2001). The main reason why a system does not meet the user's expectation is the failure in eliciting complete and precise requirements, according to these authors.

Requirement elicitation may also occur when the system acquired by an organisation needs some degree of customisation so that it can fit the business model. This step may be complex due to the great diversity of HR management models adopted by organisations. This is one of the reasons by which HRIS implementation projects have a very specific dynamics (Kavanagh, 2015).

Some authors address the issue of customisation with restrictions. Customisations are inevitable because many HR departments can perform processes differently from the functionalities provided by the system (Bedell, 2003). The more the system meets the organisation's needs, the more successful the implementation of the innovation. Customisations are viable alternatives for this purpose, despite not always providing benefits. This may be a cause of failure in the implementation projects, explain these authors.

In theory, implementing a pre-existing system acquired by an organisation is initially simple: the system is purchased, installed, started and used (Cadle \& Yeates, 2008). However, problems may begin with the choice of a system, which can better match the organisation's needs, as a large amount of peculiarities and exceptions involved makes this task complex. According to these authors, the analysis of requirements is part of the solution but some issues emerge only when the system is implemented and used.

The stress in the relationship between HRIS manufacturers and client organisations during implementation processes is addressed by Bedell (2003). Many system manufacturers report that client organisations request for customisations to facilitate upgrades and to avoid support services. On the other hand, some client organisations state that their system implementation would not be successful if customisations had not been made. Customisations in HRIS implementation projects may be problematic when the organisations take advantage of the opportunity to improve or conceal poorlydesigned processes, warn this author. This practice may affect the project's deadline and scope

Risks in implementation projects involve communication problems (Maretti, Parreira, \& Costa, 2016). They also involve frustration with expectations, lack of commitment of the involved individuals, change of course during the project, application bugs, exclusive focus on technology, system incompatible with business needs and users unprepared to operate the system (Gambôa, Caputo, \& Filho, 2004). The relevant aspects for a successful system implementation projects encompass upper management support, use of multi-professional teams, strategic partnerships, training of end-users and involvement of users (Borba, Luconi, \& Engeroff, 2007; Weersma, Marques, \& Rebouças, 2013).

\section{Users' perception of the system's characteristics}

Several variables influence the adoption of an innovation. How individuals perceive certain characteristics of an innovation may influence its rate of adoption (Rogers, 2003). These characteristics would be:

- relative advantage, which is how an innovation is perceived as better than the previous ideas; 
INMR

17,2

- compatibility, which is how an innovation is perceived as being consistent with current values, past experiences and needs;

- complexity, which is how an innovation is perceived as being difficult to understand and use;

- trialability, which is how an innovation can be experienced before its adoption; and

- observability, which is how the results of an innovation are visible to others.

Innovations perceived by individuals as being advantageous, compatible with current values, easy to understand and use, susceptible to testing and whose results are observable are those which would be more quickly adopted (Rogers, 2003).

Processes of political, cultural and institutional nature may be obstacles to the adoption of an innovation (Buschgens, Bausch, \& Balkin, 2013). Internal and external pressures can generate misalignments, and thus, provoke resistance and conflicts of interests, according to these authors. Nevertheless, these processes regarding the innovation's aspects would be collectively perceived and interpreted by the individuals.

As a result, the way by which the individuals perceive and interpret certain characteristics of HRIS may influence the degree of acceptance and use of this tool. The literature shows cases of systems, which were successfully implemented but low adhesion and discontinued use led to various types of organisational losses (Venkatesh \& Bala, 2008).

Models of acceptance and use of technology traditionally consider the user's perception of the technological resources to be prior indicators of effective acceptance and use of innovation. The technology acceptance model (Davis, 1989; Venkatesh \& Bala, 2008; Venkatesh \& Davis, 2000) is based on Ajzen's (1991) theory of planned behaviour. This model emphasises perceived usefulness and ease of use as antecedents of intended use.

The unified theory of acceptance and use of technology points to four possible antecedents of intended use (Venkatesh, Morris, Davis, \& Davis, 2003; Venkatesh, Thong, \& $\mathrm{Xu}, 2012)$. They are:

(1) performance expectancy, which corresponds to the individual's expectation in improving their own performance from the use of technology;

(2) effort expectancy, which corresponds to the individual's expectation in using an easy technology;

(3) social influence, which corresponds to how much the individual believes that the technology is important to oneself and others; and

(4) facilitating conditions, which correspond to the individual's perceptions of the resources and support to use the technology.

\section{Quality of human resource management model}

As shown earlier, the innovative potential of HRIS relies on improving the strategic management of people (Kavanagh \& Johnson, 2015) and on strengthening the HR department's role as a business partner (Kossek et al., 1994). In addition to the characteristics of the system and implementation process, another relevant aspect for this innovative potential is the quality of the management model that will be automated by the system.

A strategic HRIS usually has competency management functionalities (Kavanagh \& Johnson, 2015). They consist in guiding the efforts for planning, catchment, development and assessment of the competencies required to achieve organisational objectives (Brandão 
\& Guimarães, 2001). The concept of competency refers to a complex combination of knowledge, skills and attitudes used by an individual to reach a given purpose in the job (Abbad \& Borges-Andrade, 2014).

The competency management process automated by HRIS may fail to present accurate reliable information, for reasons other than the system itself or its implementation (McHenry \& Stronen, 2008). Indeed, poor quality of mapping, description and evaluation of competencies can lead to spurious interpretations of these data, thus generating information disconnected from the organisation's reality.

Several inter-related and inter-dependent elements are components of a strategic HRIS. If a given element does not work properly, the whole functioning of the system may be affected (Kassim, Ramaya, \& Kurnia, 2012). The strategic HRIS business rules are related to human behaviour in the workplace, which have some specificities. In fact, these systems go beyond the mere association between hardware and software. They require co-operation between departments, people, norms, policies, procedures and data (Kavanagh \& Johnson, 2015).

In synthesis, the present review suggests that the expected value aggregation provided by the systems is related to a combination between its related factors and characteristics of the implementation process and of the HR management model. A fine adjustment between these three dimensions is very likely to promote the achievement of the benefits promised by these systems.

Knowledge on how professionals involved in the system implementation perceive these aspects and how they relate them to possible benefits from the HRIS is needed. In general, these professionals are important decision-makers who may significantly influence the choice of a system and how it is implemented in the organisation. Professionals from different areas and with different experiences in the implementation process stages may have different perceptions of these aspects. Therefore, the objective of the present study was to compare the perceptions of individuals involved in the implementation of HRIS on:

- the results it should produce;

- the characteristics it should have; and

- how it should be implemented.

\section{Method}

A qualitative design was adopted for the proposed investigation, to explore a range of opinions and different representations regarding the research question (Gaskell, 2002). This investigation is a case study in which multiple cases were used to describe a phenomenon and they were compared for theory generation (Eisenhardt, 1989; Gil, 2008).

\section{Instrument construction}

Data were collected by an interview script, which was specifically elaborated to answer the study questions based on the priorly-mentioned literature review. These questions were semantically validated by two judges. One was a senior IT system developer and the other was a professor in work and organisational psychology at the University of Brasilia. The judges assessed whether the questions could elicit interpretations different from expected interpretations (Gil, 2008). The questions were individually presented to each judge, who was asked to identify the purpose of each one. They considered that the questions were fully compatible with the respective objectives. The final questionnaire consisted of six items as follows: 
INMR

17,2

204

Q1. How can a HRIS influence/affect the management of a company?

Q2. Are there gains for the employee to perform competency management through a system? If so, which ones?

Q3. How should a system be designed (what characteristics should it have), to generate gains for employees?

Q4. What are the risks, if a system will not work as expected?

Q5. Which factors are crucial in an implementation process, to reach the desirable results? (i.e. What kind of care should be taken in the implementation process so that these results may be achieved?)

Q6. How a fine adjustment between system and competency management model may be ensured?

\section{Participant selection}

A search on large organisations who had acquired and implemented HRIS and those who were in the implementation phase was conducted in Brasilia. Organisations who developed this system by themselves or who hired a software development manufacturer were not included. Large organisations were considered for study because they were more likely to have strategic HRIS (Ngai \& Wat, 2006). The system had to be a single application and execute competency management processes so that it could be characterised as a strategic HR management system (Kavanagh \& Johnson, 2015). Moreover, if the system was already implemented, it had to be in operation for at least two years - a period considered reasonable for familiarisation of employees.

Ten organisations were found to meet the inclusion criteria and four accepted to participate in the study. HRIS was already implemented in two of them and in an implementation phase in the other two organisations. The managers responsible for authorizing the investigation in each organisation also indicated the IT and HR professionals involved in the system implementation. This characterises a convenience sample (Gil, 2008). Other employees of the organisations were not included, as they could not have had contact with the implementation process. A total of 18 (ten HR and eight IT) professionals participated in the study. They were distributed as follows:

- Organisation A: Large institution (2,190 public servants) of the judiciary sector undergoing the implementation phase of HRIS. Four professionals from the HR area and two from the IT area.

- Organisation B: Large institution (2,515 public servants) of the executive sector undergoing the implementation phase of HRIS. One professional from the HR area and four from the IT area.

- Organisation C: Large private corporation (3,200 employees) operating in the financial sector with already-implemented HRIS. Two professionals from the HR area and one from the IT area.

- Organisation D: Large private corporation (1,900 employees) operating in the healthcare sector with already-implemented HRIS. Three professionals from the HR area and one from the IT area.

The system implementation project in the organisations was carried out by teams with a small number of professionals. Therefore, some precautions were taken to ensure the 
anonymity of the participants in the present study. One of these was the non-inclusion of the participant's personal data, such as gender, age and position. The participants were distributed into four quadrants depending on their professional area of expertise and type of organisation (Figure 1). These quadrants will be further used to compare the results.

Data collection and analysis processes

Individual semi-structured interviews were conducted on a face-to-face basis, except one by telephone. They were recorded. However, one participant did not allow it and answers were written. Overall, the participants tended to objectively answer the questions. The interviews lasted $12 \mathrm{~min}$, on the average.

The recorded interviews were transcripted. The content was analysed according to the method proposed by Bardin (2011). Full statements from each participant were identified and coded to form basic analysis units, the so-called themes. These themes were classified into pre-defined categories depending on their content. These categories were elaborated according to the study objectives and questions in the interview script, as follows:

- Results of the system. This category addresses the participant's perception of the results the system should provide to organisations and individuals. This category was proposed in accordance with Questions 1 and 2, based on technology acceptance models (Davis, 1989; Venkatesh \& Bala, 2008; Venkatesh \& Davis, 2000) and innovation diffusion models (Rogers, 2003). The applicants' perception of the HRIS regarding the results to be achieved is a crucial factor for the success of this kind of system (Mamun \& Islam, 2016).

- Characteristics of the system. This category addresses the participants' perception of the characteristics the system should have to provide positive results to organisations and individuals. This category was proposed in accordance with Questions 3 and 4, based on technology acceptance models (Davis, 1989; Venkatesh \& Bala, 2008; Venkatesh \& Davis, 2000) and innovation diffusion models (Rogers, 2003). Their perception of the characteristics of an innovation may influence rate of adoption and subsequent use of it (Kassim et al., 2012).

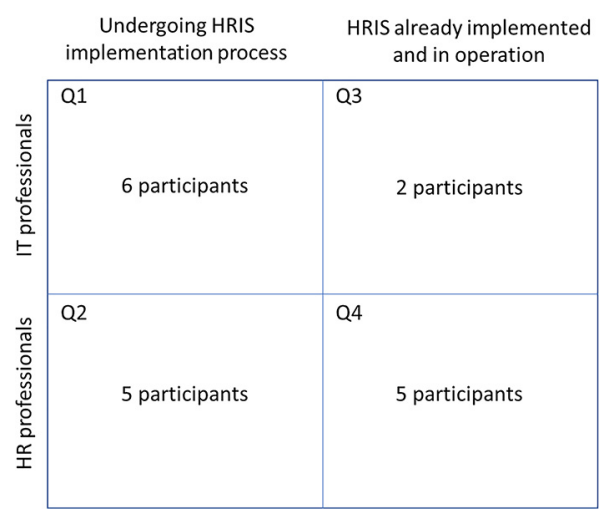

Figure 1.

Comparison quadrants between professionals and organizations 
INMR

17,2

206

- Characteristics of the implementation process. This category addresses aspects the implementation process should have so that the system can provide positive results to organisations and individuals. This category was proposed in accordance with Questions 4 and 5, based on the argument that the implementation of HRIS transcends its mere installation or availability to the organisation. This process involves political, social and managerial aspects, which can affect the success of HRIS (Bedell \& Caniff, 2015; Kavanagh \& Johnson, 2015).

- Adequacy between system and management model. This category addresses the ways to ensure an adjustment between system and management model. It was proposed in accordance with Question 6, based on the argument that HRIS functionalities need to match the organisation's HR management processes so that advantages may be really perceived (Bedell, 2003; Bedell \& Caniff, 2015; Cadle \& Yeates, 2008; Kavanagh \& Johnson, 2015).

The classification of the themes into these categories was submitted to validation by four judges, who were graduate students in work and organisational psychology. A sample of 40 themes (10 from each category) was selected for this procedure. The selected themes were those with higher and lower frequency rates in their categories and quadrants. The categories and respective definitions were initially presented to the judges. Next, the judges were asked to classify the 40 themes individually into those categories they deemed to be more appropriate. In the end, the rate of hits for each judge was considered. The judges were able to correctly classify 38.75 (mean) of the 40 themes, with a standard deviation of 1.25 . The erroneously rated themes were jointly analysed by the four judges. These themes had a low-frequency rate. After detailing the content of these themes, the unanimous decision was to classify them in the original categories. Thus, the categories were maintained.

To compare the perceptions between IT and HR professionals, the results of Quadrants 1 and 3 were aggregated and compared to those aggregated in Quadrants 2 and 4. The visual mapping technique was used for analysis and presentation of the results as it allows a great amount of information to be presented in a limited space. This helps in the observation of standards and in assessing assumptions (Langley, 1999).

\section{Results}

Content analysis was performed for each quadrant (Figure 1). The description of the results of each quadrant is separately presented. Next, the results of the comparison between HR and IT professionals are presented for comparing similarities and divergences between their perceptions.

Table I shows the results of the content analysis of the answers given by the professionals in Quadrant 1 (IT professionals from organisations in the implementation phase of HRIS).

The themes with higher occurrence were those regarding the "characteristics of the implementation process", that is, 35 per cent. In this category, the most frequently mentioned theme was "requirements elicitation". For these professionals, "ease of use" was the most cited characteristic of the system. The theme had the highest rate in this group.

Table II shows the results for the content analysis of the answers given by the professionals in Quadrant 2 (HR professionals from organisations in the implementation phase of HRIS).

Most of the answers given by these professionals were concentrated on the results the system may achieve. In this category, the theme "quality of information on employees" was 


\begin{tabular}{|c|c|c|c|c|}
\hline Category & Themes & Freq. & $(\%)$ & Human \\
\hline \multirow[t]{9}{*}{ Results of the system } & Enabling the execution of HR processes & 9 & \multirow[t]{9}{*}{29.7} & \\
\hline & Quality of the HR processes & 5 & & \\
\hline & Individual development of the employee & 5 & & \\
\hline & Increase in the organisation's capacity of data processing & 4 & & \\
\hline & Increase in the organisation's capacity of control & 4 & & \\
\hline & Broadening of the view of the employees & 4 & & 207 \\
\hline & Access to information by employees and managers & 2 & & \\
\hline & Autonomy for employees to perform operations & 1 & & \\
\hline & Documentation and formalisation of information & 1 & & \\
\hline \multirow{5}{*}{$\begin{array}{l}\text { Characteristics of the } \\
\text { system }\end{array}$} & Ease of use & 15 & \multirow[t]{5}{*}{22.0} & \\
\hline & Friendly and familiar interface & 7 & & \\
\hline & Acceptance of the individual's routine & 2 & & \\
\hline & Flexible & 1 & & \\
\hline & Integrated information & 1 & & \\
\hline \multirow{8}{*}{$\begin{array}{l}\text { Characteristics of the } \\
\text { implementation process }\end{array}$} & Requirements elicitation & 10 & \multirow[t]{8}{*}{35} & \\
\hline & Scope control & 6 & & \\
\hline & $\begin{array}{l}\text { Application of methods and techniques of project } \\
\text { management }\end{array}$ & 6 & & \\
\hline & $\begin{array}{l}\text { Promotion of actions to increase people's confidence in } \\
\text { the system }\end{array}$ & 6 & & \\
\hline & Stakeholder expectations management & 5 & & \\
\hline & Organisation's culture management & 3 & & \\
\hline & Qualification of the users & 3 & & \\
\hline & Management of acquisition process & 2 & & \\
\hline \multirow{4}{*}{$\begin{array}{l}\text { Adequacy between system } \\
\text { and management model }\end{array}$} & Customisation/parameterisation & 6 & \multirow[t]{4}{*}{14} & Table 1. \\
\hline & Maturity of the model & 5 & & Results for \\
\hline & Search for tools matching the model & 3 & & participants in \\
\hline & Mapping of the process before execution of the project & 2 & & quadrant 1 \\
\hline
\end{tabular}

most frequently cited. Moreover, "ease of use" was the most cited characteristic of HRIS and the theme had the highest rate in this group.

Table III shows the results of the content analysis of the answers given by the professionals in Quadrant 3 (IT professionals from organisations with already-implemented HRIS).

The theme "requirements elicitation" was the most cited. The category into which this theme was classified ("characteristics of the implementation process") also had the highest occurrence (41 per cent).

Table IV presents the results of the content analysis of the answers given by the professionals in Quadrant 4 (HR professionals from organisations with alreadyimplemented HRIS).

The most recurrent theme for these professionals was "ease of use", which is the characteristic a system should have. Nevertheless, the most frequently cited category was "characteristics of the implementation process".

The results of the comparison between the perceptions of IT and HR professionals are shown in Figure 2. The most frequently cited categories were "characteristics of the implementation process" for IT professionals (37 per cent) and "results of the system" for HR professionals (39 per cent).

The theme "ease of use" was the most frequently cited by both IT and HR professionals. It corresponds to 50 per cent of the occurrences regarding the characteristics of the system. On the 


\section{INMR}

17,2

\begin{tabular}{llcc}
\hline Category & Themes & Freq. & (\%) \\
\hline Results of the system & Quality of information on employees & 9 & 42.2 \\
& Career planning by employees & 8 & \\
& Broadening of the view of the employees & 6 & \\
& Access to feedback by the employees & 5 & \\
& Access to information by employees and managers & 5 & \\
& Quality of the HR processes & 4 & \\
& Integration of the HR systems & 4 & \\
& Individual development of the employee & 4 & \\
& Management decision-making & 1 & \\
& Development of the organisation's strategic maturity & 1 & \\
& Flexibility to respond to demands & 1 & \\
& Enabling the execution of HR processes & 1 & \\
Characteristics of the system & Ease of use & 14 & 31.0 \\
& Flexible & 5 & \\
& Adherence to the HR model & 5 & \\
& Stable & 2 & \\
& High-capacity data processing & 2 & \\
& Data integration capacity & 2 & \\
& Wide-ranging & 2 & \\
& Available & 2 & \\
Characteristics of the & Useful & 2 & \\
implementation process & Articulation with stakeholders & 12 & 22 \\
& Qualification of the users & 4 & \\
& Good communication among implementation team members & 4 & \\
Adequacy between system & Organisation's culture management & 3 & \\
and management model & Adequate profile of the implementation professionals & 2 & \\
& Customisation/parameterisation & 4 & 5 \\
& Performing tests and adjustments & 2 & \\
\hline
\end{tabular}

Table II.

Results for participants in quadrant 2 and management model
Customisation/parameterisation
Performing tests and adjustment

\begin{tabular}{llcc}
\hline Category & Themes & Freq. & (\%) \\
\hline Results of the system & Automation of HR processes & 5 & \multirow{2}{*}{31.8} \\
& Individual development of the employee & 5 & \\
& Enabling strategic management of the HR & 4 & \\
& Enabling the execution of HR processes & 3 & \\
& Documentation and formalisation of information & 2 & \\
& Flexibility to respond to demands & 2 & \multirow{2}{*}{19.7} \\
Characteristics of the system & Ease of use & 5 & \\
& Flexible & 3 & \\
& Quality of HR management model & 3 & \\
Characteristics of the & Stable & 1 & \\
implementation process & Useful & 1 & \multirow{2}{*}{41} \\
& Requirements elicitation & 12 & \\
& Analysis of the organisation's needs & 6 & \\
& Scope control & 5 & \\
& Application of methods and techniques of project & 2 & \\
Adequacy between system & management & 1 & \\
and management model & Involvement of stakeholders & 1 & \multirow{2}{*}{8} \\
& Allowing pilot project to be performed & 2 & \\
& Customisation/parameterisation & 3 & \\
& Maturity of the model & &
\end{tabular}

Table III.

Results for participants in quadrant 3 and management model 


\begin{tabular}{|c|c|c|c|c|}
\hline Category & Themes & Freq. & $(\%)$ & Human \\
\hline \multirow[t]{8}{*}{ Results of the system } & $\begin{array}{l}\text { Promoting employee access to technology } \\
\text { Access to feedback by employees }\end{array}$ & $\begin{array}{l}7 \\
5\end{array}$ & \multirow[t]{8}{*}{34.4} & system \\
\hline & Employee recognition by the organisation & $\begin{array}{l}5 \\
4\end{array}$ & & \\
\hline & Enabling the execution of HR processes & 3 & & \\
\hline & Broadening of the view of the employees & 3 & & \\
\hline & Flexibility to respond to demands & 3 & & 209 \\
\hline & Access to information by employees and managers & 3 & & \\
\hline & Virtual experience customisation by the employee & 3 & & \\
\hline & Autonomy for the employee perform operations & 1 & & \\
\hline \multirow[t]{3}{*}{ Characteristics of the system } & Ease of use & 15 & \multirow[t]{3}{*}{21.5} & \\
\hline & Friendly and familiar interface & 3 & & \\
\hline & Available & 2 & & \\
\hline \multirow{10}{*}{$\begin{array}{l}\text { Characteristics of the } \\
\text { implementation process }\end{array}$} & Adequate profile of the implementation professionals & 6 & \multirow[t]{10}{*}{38} & \\
\hline & Requirements elicitation & 6 & & \\
\hline & Scope control & 5 & & \\
\hline & Application of methods and techniques of project management & 5 & & \\
\hline & Good communication between IT and HR professionals & 5 & & \\
\hline & Following up the project & 4 & & \\
\hline & Performing benchmarking & 1 & & \\
\hline & Promotion of actions to increase people's confidence in the system & 1 & & \\
\hline & Infra-structure tests & 1 & & \\
\hline & Stakeholder expectations management & 1 & & Results for \\
\hline \multirow{2}{*}{$\begin{array}{l}\text { Adequacy between system } \\
\text { and management model }\end{array}$} & Customisation/parameterisation & 3 & \multirow[t]{2}{*}{6} & participants in \\
\hline & Maturity of the model & 3 & & quadrant 4 \\
\hline
\end{tabular}

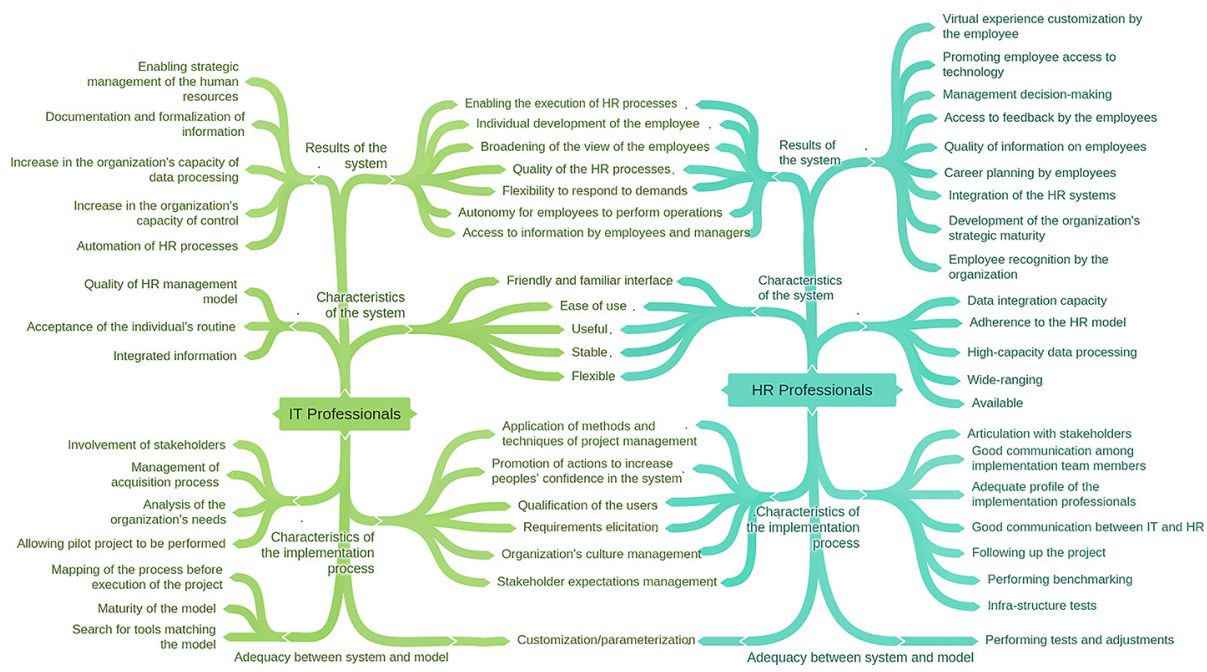

Figure 2. Comparisons between IT and HR professionals

average, 31 per cent of the themes in each category were cited by both groups of professionals. Themes cited only by IT professionals were those focusing on organisational results, organisational needs analysis and acquisition process. Themes cited only by HR professionals were those focussing on results for individuals and processes of policy and communication. 
INMR

17,2

\section{Discussion}

By means of interviews with professionals from the IT and HR areas, the following questions were answered: How do individuals involved in the implementation of a HRIS perceive its potentialities, characteristics and implementation process? Do professionals from different areas and at different stages of the implementation process share a homogeneous view of what they are acquiring and for what? Do these professionals emphasise the same aspects of the implementation process? From these results, participants' perceptions were compared, similarities and differences were identified, and the research questions were answered.

The organisation may benefit from the innovative potential of HRIS, by improving the strategic management of people and strengthening the HR department role as a business partner of the organisation. This depends on certain characteristics of the system and it must match the organisational needs and be actually used by individuals.

Homogeneous perceptions of what a system is and what it is for may be positive when they correspond to the reality of HRIS. On the other hand, when the perceptions converge towards ill-grounded unconscious expectations, they may represent a risk to these types of projects. Similarly, heterogeneous perceptions can be positive if they complement each other. For example, emphasizing different aspects of the implementation process can be advantageous, if the project team is multiprofessional and it has a high-quality communication process.

Regarding the convergence of perceptions, the most recurrent theme was "ease of use", which corresponds to a characteristic the system should have. The degree to which an innovation is perceived as being difficult to use may influence its rate of adoption, according to the innovation diffusion model proposed by Rogers (2003). Moreover, the belief or expectation that using a system will be effortless can facilitate its acceptance and its effective use by the users, according to technology acceptance models (Davis, 1989; Venkatesh \& Bala, 2008; Venkatesh \& Davis, 2000) and unified theory of acceptance and use of technology (Venkatesh et al., 2003, 2012).

The less frequently mentioned characteristics of the system were utility, stability and availability. Interestingly, the system's security (i.e. data on users cannot be leaked or lost) or applications free of bugs was not mentioned. The choice of the best option in the market is not a simple process because several characteristics of the system must be considered (Cadle \& Yeates, 2008). Instability, unavailability, insecurity and high presence of bugs are aspects of a system, which can reduce its rate of adoption, such as a complex, non-friendly system. In addition to the choice of intuitive systems with friendly interface and within the required requirements, other initiatives may increase the likelihood that the system will be used. These initiatives include qualification training and pilot projects for experimental use of the system (Kossek et al., 1994; Rogers, 2003).

The most frequently-mentioned category was "characteristics of implementation process", among the professionals of Quadrants 1, 3 and 4. They also recurrently cited the themes "requirements elicitation", "scope control" and "application of methods and techniques of project management". Only HR professionals involved in the implementation phase of the system (Quadrant 2) did not mention these themes. HR professionals from organisations with already-implemented system and IT professionals may have similar answers because the former had participated in the system implementation. It is important that HR professionals have a clear view of the complexity of the HRIS implementation process. They need this type of system and they are key agents in the adoption of innovation and organisational changes. 
The results shown in Figure 2 suggest that both IT and HR professionals consider the implementation process under different perspectives. In general, the HR area demands this type of system and its professionals may be a higher interested in its effective use and in the results provided to the individuals. On the other hand, IT professionals are more worried with technical aspects of the implementation process and with favourable results for the organisation. The importance of the quality of communication between the individuals involved in the HRIS implementation may also be highlighted. This would result in complementary between different perspectives and would allow a broader view of the process.

Regarding the adequacy between system and management model, the most frequently cited themes were "customisation/parameterisation" and "maturity of the model". These results indicate that the respondents perceive that the system must fit to the management model, meaning that some level of customisation/parameterisation is necessary. However, the management model must be well designed and be well-known by the involved individuals. On the other hand, an extensive customisation may interfere with the execution of the project.

Most of the systems allow a certain level of customisation, but some organisations perform activities in a very particular way, which is neither supported by the system nor easily adapted to changes. From the manufacturers' perspective, it is very important that they manage the clients' expectation so that there is no disappointment with the system in terms of expected and real results (Cadle \& Yeates, 2008). Customisations should be performed if: there is a solid business reason for doing so; and customisation can be made and maintained at a cost lower than the benefits (Bedell, 2003).

The present study has limitations. The number of participants in each comparison quadrant and number of professionals between the organisations studied were not similar. The composition of quadrants and the legal nature of the organisations introduced a bias that limits the present study. Already-implemented systems were in private organisations, whereas the public organisations were those undergoing the implementation process. Therefore, comparisons between different stages of implementation were not performed because we would be comparing public and private organisations. Another limitation was the lack of information on the respondents, as a result of anonymity.

As a research agenda, we suggest that longitudinal studies should be performed, in which assessments are made before and after the system implementation. This would more accurately identify the effect of this process on the participants' perceptions. Predictive testing models using inferential statistics analyses are scanty in this area. They would advance the understanding of adoption of this type of innovation.

\section{Conclusion}

The present study pointed to alternatives, which should be considered by organisations, to face the challenges inherent to the acquisition and implementation of a HRIS. It sought to provide knowledge on models of innovation adoption and acceptance of technology, by demonstrating similarities and differences between the professional's perceptions about the HRIS implementation. This study also sought to provide information to the HR management field, by pointing to some possible HRIS requirements that may benefit their innovative potential to organisations. A methodological contribution was the use of content analysis of 18 interviews, for comparing four-quadrant groups representing different contexts and professional areas.

HRIS need to improve the strategic management of people and to strengthen the HR department as a business partner of the organisation. This is achieved if they have certain characteristics and if their implementation follows certain standards. These characteristics and standards are perceived and interpreted by professionals involved in the implementation process. The issues raised here may guide them in the acquisition, development and 
INMR

17,2

implementation of HRIS. On choosing the best option in the market, it is important to consider the real need of the organisation and the results that the system can produce, to reduce customisations. It is also important to consider other characteristics of the system, as well as ease of use. As for the process of implementation itself, one should consider multiprofessional teams in the areas of IT, HR and project management; and to adopt mechanisms to manage communication and expectations among the involved individuals.

The great diversity of human management models, HRIS implementation projects usually allow a certain degree of customisation. Our results and the literature suggest that the organisation's professionals tend to require customisations to fit the system to the HR model. The processes to be automated should be revised before the implementation. They should not be revised during the HRIS implementation. This approach may avoid interferences with the project's parameters. A thorough assessment of customisations needs should be carried out, as they may be either beneficial or harmful to implementation projects.

\section{References}

Abbad, G. S., \& Borges-Andrade, J. E. (2014). Aprendisagem humana em organisações e trabalho. In J. C. Zanelli, J. E. Borges-Andrade, \& A. V. B. Bastos, (Eds.), Psicologia, organisações e trabalho no Brasil, São Paulo, SP: Artmed, pp. 244-284.

Ajzen, I. (1991). The theory of planned behavior. Organisational Behavior and Human Decision Processes, 50, 179-211. Retrieved from https://www.sciencedirect.com/science/article/abs/pii/ 074959789190020T, https://doi.org/10.1016/0749-5978(91)90020-T

Alves, M. F. R., Galina, S. V. R., \& Dobelin, S. (2018). Literature on organisational innovation: past and future. Innovation \& Management Review, 15, 2-19, https://doi.org/10.1108/INMR-01-2018-001.

Ball, K. S. (2001). The use of human resource information systems: a survey. Personnel Review, 30, 677-693, https://doi. org/10.1108/EUM0000000005979.

Bardin, L. (2011). Análise de conteúdo, 70, São Paulo, Brazil: Edições.

Bedell, M. (2003). Human resources information systems. In H. Bidgoli, (Ed.), The encyclopedia of information systems 537-549. Cambridge, MA: Academic Press.

Bedell, M. D., \& Caniff, M. L. (2015). Systems considerations in the design of a human resource information system: planning for implementation. In M. J. Kanavagh, M. Thite, \& R. D. Johnson, (Eds.), Human resource information systems: Basics, applications, and future decisions, 135-164. London, England: Sage.

Bondarouk, T., \& Ruel, H. (2010). The strategic value of e-HRM: results from an exploratory study in a governmental organisation. Third European Academic Workshop on Electronic Human Resource Management, Taylor \& Francis, Bamberg, Germany, 15-32. Retrieved from http:// ceur-ws.org/Vol-570/

Borba, G. S., Luconi, C., \& Engeroff, R. (2007). Análise do processo da implantação de um sistema ERP em uma universidade. XXXI encontro da ANPAD, ANPAD, Rio de Janeiro, RJ, Brasil, 1-13. Retrieved from http://www.anpad.org.br/admin/pdf/ADI-A1876.pdf

Brandão, H. P., \& Guimarães, T. A. (2001). Gestão de competências e gestão de desempenho: tecnologias distintas ou instrumentos de um mesmo construto?. Revista de Administração de Empresas RAE, 41, 8-15. Retrieved from https://rae.fgv.br/rae/vol41-num1-2001/gestaocompetencias-gestao-desempenho-tecnologias-distintas-ou-instrumentos, https://doi.org/10.1590/ S0034-75902001000100002.

Broderick, R., \& Boudreau, J. W. (1992). Human resource management, information technology and the competitive edge. Academy of Management Perspectives, 6, 7-17. Retrieved from https:/journals. aom.org/doi/abs/10.5465/ame.1992.4274391, https://doi.org/10.5465/ame.1992.4274391.

Browne, G. J., \& Rogich, M. B. (2001). An empirical investigation of user requirements elicitation: comparing the effectiveness of prompting techniques. Journal of Management Information 
Systems, 17, 223-249. Retrieved from https://www.jstor.org/stable/40398511?seq=1\#page_ scan_tab_contents, https://doi.org/10.1080/07421222.2001.11045665.

Buschgens, T., Bausch, A., \& Balkin, D. B. (2013). Organisational culture and innovation: a Meta-analytic review. Journal of Product Innovation Management, 30, 763-781. https://doi.org/10.1111/jpim.12021.

Cadle, J., \& Yeates, D. (2008). Project management for information systems, Harlow: Prentice-Hall.

Crook, T. R., Todd, S. Y., Combs, J. G., Woehr, D. J., \& Ketchen, D. J. Jr (2011). Does human capital matter? A meta-analysis of the relationship between human capital and firm performance. Journal of Applied Psychology, 96, 443-456. Retrieved from https://psycnet.apa.org/record/201100496-001, https://doi.org/10.1037/a0022147.

Damanpour, F., \& Schneider, M. (2006). Phases of the adoption of innovations in organisations: Effects of environment, organisation and top managers. British Journal of Management, 17, 215-236. https:// doi.org/10.1111/j.1467-8551.2006.00498.x.

Damanpour, F., Walker, R. M., \& Avellaneda, C. N. (2009). Combinative effects of innovation types and organisational performance: a longitudinal study of service organisations. Journal of Management Studies, 46, 650-675. https://doi.org/10.1111/j.1467-6486.2008.00814.x.

Davis, F. (1989). Perceived usefulness, perceived ease of use, and user acceptance of information technology. MIS Quarterly, 13, 319-340. Retrieved from https://www.jstor.org/stable/249008? seq=1\#page_scan_tab_contents, https://doi.org/10.2307/249008.

Eisenhardt, K. M. (1989). Building theories from case study research. Academy of Management Review, 14, 532-550. Retrieved from https://journals.aom.org/doi/10.5465/amr.1989.4308385, https://doi. org/10.5465/amr.1989.4308385.

Fletcher, P. A. K. (2005). From personnel administration to business-driven human capital management: the transformation of the role of HR in the digital age. In H. G. Guetal, \& D. L. Stone, (Eds.), The brave new world of eRH: Human resource management in the digital era, 1-21. San Francisco, CA: Jossey-Bass.

Gambôa, F. A. R., Caputo, M. S., \& Filho, E. B. (2004). Método Para gestão de riscos em implementações de sistemas ERP baseado em fatores críticos de sucesso. Revista de Gestão da Tecnologia e Sistemas de Informação, 1, 45-62, https://doi. org/10.1590/S1807-17752004000100004.

Gaskell, G. (2002). Entrevistas individuais e grupais. In W. M. Bauer, \& G. Gaskell, (Eds.), Pesquisa qualitativa com texto, imagem e som: um manual prático, 64-89. Petrópolis, RJ: Vozes.

Gil, A. C. (2008). Métodos e técnicas de pesquisa social, São Paulo, SP: Atlas.

Johnson, R. D., Lukaszewski, K. M., \& Stone, D. L. (2016). The evolution of the field of human resource information systems: co-evolution of technology and HR processes. Communications of the Association for Information Systems, 38, 533-553. Retrieved from https://aisel.aisnet.org/cais/ vol38/iss1/28/, https://doi.org/10.17705/1CAIS.03828.

Kassim, N., Ramaya, T., \& Kurnia, S. (2012). Antecedents and outcomes of human resource information system (HRIS) use. International Joumal of Productivity and Performance Management, 61, 603-623. https://doi.org/10.1108/17410401211249184.

Kavanagh, M. J. (2015). Project management and human resource management: advice for human resource information systems implementation. In M. J. Kavanagh, M. Thite, \& R. D. Johnson, (Eds.), Human resource information systems: Basics, applications, and future decisions, 135-164. London, England: Sage.

Kavanagh, M. J., \& Johnson, R. D. (2015). Evolution of human resource management and human resource information systems: the role of information technology. In M. J. Kavanagh, M. Thite, \& R. D. Johnson, (Eds.), Human resource information systems: Basics, applications, and future decisions (pp. 1-33). London, England: Sage. In

Kraiger, K., Passmore, J., Santos, N. R., \& Malvezzi, S. (2015). The psychology of training, development and performance improvement. In K. Kraiger, J. Passmore, N. R. Santos, \& S. Malvezzi, (Eds.), The Wiley Blackwell handbook of the psychology of training, development and performance improvement (pp. 1-9). Chichester, England: John Wiley \& Sons. 
INMR

17,2

Kossek, E. E., Young, W., Gash, D. C., \& Nichol, V. (1994). Waiting for innovation in the human resources department: Godot implements a human resource information system. Human Resource Management, 33, 135-159. https://doi.org/10.1002/hrm.3930330108.

Langley, A. (1999). Strategies for theorizing from process data. The Academy of Management Review, 24, 691-710. https://doi.org/10.2307/259349.

McHenry, J. E. H., \& Stronen, F. H. (2008). The trickiness of IT enhanced competence management. Journal of Workplace Learning, 20, 114-132. https://doi.org/10.1108/13665620810852278.

Maretti, V., Parreira, P. A., Jr, \& Costa, H. (2016). Uma revisão sistemática da literatura sobre comunicação no contexto da gerência de projetos de sistemas de informação. XII Brazilian Symposium on Information Systems, SBC, Florianópolis, Brasil, 84-91. Retrieved from https:// sol.sbc.org.br/index.php/sbsi/article/view/5949

Mamun, A. A., \& Islam, S. (2016). Perception of management on outcomes of human resource information system (HRIS). International Journal of Business and Social Research, 6, 29-37. Retrieved from https://thejournalofbusiness.org/index.php/site/article/view/837, https://doi.org/ 10.18533/ijbsr.v6i2.837.

Ngai, E. W. T., \& Wat, F. K. T. (2006). Human resource information systems: a review and empirical analysis. Personnel Review, 35, 279-314. https://doi.org/10.1108/00483480610656702.

Noe, R. A., Clarke, A. D. M., \& Klein, H. J. (2014). Learning in the twenty-first-century workplace. Annual Review of Organisational Psychology and Organisational Behavior, 1, 4.1-4.31. https://doi.org/ 10.1146/annurev-orgpsych-031413-091321.

Rogers, E. M. (2003). Diffusion of innovation, New York, NY: The Free Press.

Tannenbaum, S. I. (1990). Human resource information systems: user group implications. Journal of System Management, 41, 26-27. Retrieved from https://search.proquest.com/openview/ 65a6d83e1080fdc2f1ca947be8ead040/1?pq-origsite $=$ gscholar\&cbl=40682

Venkatesh, V., \& Bala, H. (2008). Technology acceptance model 3 and a research agenda on interventions. Decision Sciences, 39, 273-315. https://doi.org/10.1111/j.1540-5915.2008.00192.x.

Venkatesh, V., \& Davis, F. D. (2000). A theoretical extension of the technology acceptance model: four longitudinal field studies. Management Science, 46, 186-204. https://oi.org/10.1287/ mnsc.46.2.186.11926.

Venkatesh, V., Thong, J. Y. L., \& Xu, X. (2012). Consumer acceptance and use of information technology: extending the unified theory of acceptance and use of technology. MIS Quarterly, 36, 157-178. https://doi.org/10.2307/41410412.

Venkatesh, V., Morris, M. G., Davis, G. B., \& Davis, F. B. (2003). User acceptance of information technology: toward a unified view. MIS Quarterly, 27, 425-478. https://doi.org/10.2307/30036540.

Weersma, M. R., Marques, E. V., \& Rebouças, S. M. D. P. (2013). Fatores críticos de sucesso para a implementação de sistemas de informação: um estudo na indústria cearense de transformação. XVI Simpósio de Administração da Produção, Logística e Operações Internacionais, SIMPOI, São Paulo, Brasil, 1-14.

Zuboff, S. (1994). Automatisar/informatisar: as duas faces da tecnologia inteligente. Revista de Administração de Empresas RAE, 34, 80-91. https://doi.org/10.1590/S0034-75901994000600009.

\section{Corresponding author}

Túlio Gomes Mauro can be contacted at: tuliomauro@gmail.com

For instructions on how to order reprints of this article, please visit our website:

www.emeraldgrouppublishing.com/licensing/reprints.htm

Or contact us for further details: permissions@emeraldinsight.com 